\title{
PENGARUH MODEL PEMBELAJARAN INQUIRY TRAINING DAN MOTIVASI TERHADAP HASIL BELAJAR SISWA PADAMATERI POKOK FLUIDA STATIS KELAS X SEMESTER II SALAH SATU SMA NEGERI DI PERCUT SEI TUAN T.P. 2014/2015
}

\author{
Novera Amalia Nst dan Jurubahasa Sinuraya \\ Jurusan Fisika FMIPA Universitas Negeri Medan \\ noveraamalia@gmail.com
}

\begin{abstract}
ABSTRAK
Penelitian ini bertujuan untuk mengetahui apakah terdapat interaksi antara model pembelajaran dengan motivasi terhadap hasil belajar siswa. Jenis penelitian ini adalah quasi- eksperiment. Populasi dalam penelitian adalah seluruh siswa kelas X Semester II di SMA Negeri 1 Percut Sei Tuan T.P. 2014/2015. Sampel penelitian terdiri dari dua kelas dengan jumlah sampel 74 orang, yaitu X MIA-2 sebagai kelas eksperimen dan kelas X MIA-4 sebagai kelas kontrol. Data hasil belajar dikumpulkan dengan tes berbentuk esai. Hasil dari pengujian data menunjukkan bahwa data berdistribusi normal dan homogen. Hipotesis dianalisis menggunakan ANOVA Univariate pada taraf signifikan 0,05 dengan bantuan SPSS 20.0 for windows. Berdasarkan analisis data dan uji hipotesis yang dilakukan diperoleh bahwa tidak terdapat interaksi antara model pembelajaran dengan motivasi terhadap hasil belajar siswa.
\end{abstract}

Kata kunci : inquiry training, motivasi, hasil belajar

\begin{abstract}
The purposes of this research to determine whether there is an interaction between models learning with motivation on student learning outcomes. This research is a quasi- experiment. The population in this research was all students in class $X$ Semester II SMA Negeri 1 Percut Sei Tuan T.P. 2014/2015. The sample of this research was consisted of two classes with a sample of 74 peoples, the XMIA-2 as a class experiment and X MIA-4 as a control class. The data of learning outcomes collected in essay test. Results of the test data indicates that test distribution is normal and homogeny. Hypotheses were analyzed using the ANOVA Univariate at significant level of 0.05 using SPSS 20.0 for Windows. Based on data analysis and hypothesis testing conducted found that there was no interaction between models learning with motivation on student learning outcomes.
\end{abstract}

Keywords: inquiry training, motivation, learning outcomes.

\section{PENDAHULUAN}

Salah satu tantangan dalam dunia pendidikan untuk terus meningkatkan kualitas diantaranya yaitu melalui proses belajar mengajar. Keberhasilan proses belajar mengajar, pada intinya tertumpu pada suatu persoalan, yaitu bagaimana guru memberikan pembelajaran yang memungkinkan bagi siswa terjadi proses belajar yang efektif atau dapat mencapai hasil sesuai dengan tujuan.

Kenyataannya dewasa ini pendidikan di Indonesia belum siap menjawab tantangan tersebut. Masalah utama dalam pembelajaran pada pendidikan formal (sekolah) adalah masih memberikan dominasi guru dan 
tidak memberikan akses bagi anak didik untuk berkembang secara mandiri melalui penemuan dalam proses berpikirnya. Hal ini merupakan hasil kondisi pembelajaran yang masih bersifat konvensional dan suasana kelas cenderung teacher-centered sehingga siswa menjadi pasif (Trianto, 2011).

Hal tersebut sejalan dengan hasil observasi ke salah satu SMA Negeri Percut Sei Tuan,berdasarkan hasil wawancara kepada seorang guru fisika, diperoleh informasi bahwa metode pembelajaran yang diterapkan oleh guru fisika kelas $\mathrm{X}$ tersebut adalah metode ceramah, diskusi kelompok dan penugasan (Nasution, 2015). Gagasan diatas diperkuat oleh pendapat Harahap dan Sinuraya (2014) yang menyatakan bahwa siswa mampu menghapal teori dan membahas soal bersama guru. Namun, jika disajikan masalah yang berkaitan dengan konsep fisika mereka belum mampu memecahkannya.Hal ini dikarenakan siswa belum memahami konsep fisika, sehingga siswa menjadi tidak aktif dan fisika menjadi salah satu pelajaran yang sulit dipahami dan kurang diminati siswa. Djamarah (2011) mengatakan bahwa minat belajar yang besar cenderung menghasilkan prestasi yang tinggi, sebaliknya minat belajar kurang akan menghasilkan prestasi yang rendah.

Febrianto dan Rani (2013) berpendapat bahwa faktor yang memiliki pengaruh besar terhadap kesuksesan dalam belajar adalah motivasi belajar. Siswa akan melakukan suatu proses belajar betapun beratnya jika ia mempunyai motivasi tinggi. Siswa yang memiliki motivasi tinggi diduga akan memperoleh hasil belajar yang baik. Pentingnya motivasi belajar siswa terbentuk antara lain agar terjadi perubahan belajar ke arah yang lebih positif. Siswa yang termotivasi dengan baik dalam belajar melakukan kegiatan lebih banyak dan lebih cepat dibandingkan dengan siswa yang kurang termotivasi. Gagasan tersebut diperkuat oleh Sardiman (2011) bahwa "ketepatan pemberian motivasi akan menghasilkan hasil belajar yang optimal".

Salah satu upaya yang dapat dilakukan untuk menyelesaikan masalah-masalah diatas adalah dengan menerapkan model pembelajaran inquiry training. Menurut Pandey,dkk (2011) mengatakan bahwa model inquiry traininglebih efektif daripadapengajaranmelaluimetodekonv ensionalpada tingkat sekolah menengah.Menurut Joyce, dkk (2011) model pembelajaran inquiry training dirancang untuk membawa siswa secara langsung ke dalam proses ilmiah melalui latihan-latihan yang dapat memadatkan proses ilmiah tersebut ke dalam periode waktu yang singkat. Tujuannya adalah membantu siswa mengembangkan disiplin dan mengembangkan keterampilan intelektual yang diperlukan untuk mengajukan pertanyaan dan menemukan jawabannya berdasarkan rasa ingin tahunya. Trianto (2011) mengemukakan bahwa keterampilan inkuiri siswa meningkat dan motivasi belajarnya juga meningkat.

Model pembelajaran inquiry training diterapkan pada proses pembelajaran dengan memahami materi pelajaran yang akan disampaikan oleh guru, sehingga model ini dapat mencapai tujuan yang diharapkan. Materi yang digunakan dalam penerapan model pembelajaran ini adalah materi yang membahas tentang konsep dan prinsip, yaitu materi fluida statis karena menuntut siswa lebih aktif menemukan serta memahami konsep fluida statis dan lebih banyak dalam penerapan konsep sesuai tuntutan kompetensi.

$$
\text { Joyce, dkk }
$$

mengemukakan bahwa bermula dari seorang pengembang model inquiry training yang tertarik untuk membantu siswa meneliti secara mandiri, tetapi 
dalam cara yang disiplin. Dia ingin siswa-siswanya bertanya mengapa sesuatu peristiwa tertentu harus terjadi seperti itu, ada apa sebenarnya dan bagaimana saya bisa menyelidikinya. Serta inginsiswanya memperoleh dan memperoses data secara logis dengan mengembangkan strategi-strategi intelektual umum yang dapat siswa gunakan untuk mencari tahu terjadinya fenomena atau peristiwa tertentu.

Motivasi belajar adalah sesuatu yang mendorong siswa untuk berperilaku yang langsung menyebabkan munculnya perilaku dalam belajar (Sumiati dan Asra, 2013). Annurrahman (2009) juga menyatakan bahwa motivasi di dalam kegiatan belajar merupakan kekuatan yang dapat menjadi tenaga pendorong bagi siswa untuk memberdayakan potensipotensi yang ada pada dirinya dan potensi-potensi yang ada pada dirinya dan potensi di luar dirinya untuk mewujudkan tujuan belajar. Prayitno (1989) mengemukakan bahwa motivasi dalam belajar dapat dilihat dari karakteristik tingkah laku siswa yang menyangkut minat, ketajaman perhatian, konsentrasi dan ketekunan.

\section{METODE PENELITIAN}

Jenis penelitian ini adalah quasi- eksperiment dengan desain One Group Pretest-Postest Design. Hasil pengujian hipotesis menggunakan Analisis Varians (ANAVA) 2 jalur yang tercantum pada Tabel 1. Populasi dalam penelitian adalah seluruh siswa kelas X Semester II pada salah satu SMA Negeri di Percut Sei Tuan T.P. 2014/2015. Sampel penelitian terdiri dari dua kelas, yaitu X MIA-2 sebagai kelas eksperimen menggunakan model pembelajaran inquiry training sebanyak 36 orang dan kelas X MIA-4 sebagai kelas kontrol menggunakan pembelajaran konvensional sebanyak 38 orang. Tes hasil belajar berbentuk esai berjumlah dengan 8 butir pada materi pokok fluida statis.
Tabel 1. Desain Penelitian ANAVA 2 Jalur

\begin{tabular}{|c|c|c|c|}
\hline \multirow[b]{2}{*}{$\begin{array}{l}\text { Motivasi } \\
\text { (B) }\end{array}$} & \multicolumn{2}{|c|}{ Model Pembelajaran (A) } & \multirow[b]{2}{*}{$\begin{array}{l}\text { Re- }^{-} \\
\text {Rata }\end{array}$} \\
\hline & $\begin{array}{l}\text { Inquiry } \\
\text { Training } \\
\text { (1) }\end{array}$ & $\begin{array}{l}\text { Pembelajaran } \\
\text { Konvensional } \\
(2)\end{array}$ & \\
\hline $\begin{array}{l}\text { Rendah } \\
\text { (1) }\end{array}$ & $\mu_{11}$ & $\mu_{12}$ & $\mu_{R}$ \\
\hline $\begin{array}{l}\text { Tinggi } \\
\text { (2) }\end{array}$ & $\mu_{21}$ & $\mu_{22}$ & $\mu_{T}$ \\
\hline Rerata & $\mu_{e}$ & $\mu_{k}$ & \\
\hline
\end{tabular}

Keterangan :

$\mu_{11}:$ Rerata motivasi rendah dengan Inquiry Training

$\mu_{12}$ : Rerata motivasi rendah dengan pembelajaran konvensional

$\mu_{21}$ : Rerata motivasi tinggi dengan Inquiry Training

$\mu_{22}$ : Rerata motivasi tinggi dengan pembelajaran konvensional

$\mu_{e} \quad$ : Rerata hasil belajar dengan Inquiry Training

$\mu_{k} \quad$ :Rerata hasil belajar dengan pembelajaran konvensional

$\mu_{R}$ : Rerata hasil belajar dengan motivasi rendah

$\mu_{T} \quad$ : Rerata hasil belajar dengan motivasi tinggi

\section{HASIL DAN PEMBAHASAN Hasil}

Sebelum analisis kesamaan dua rerata (uji t dua pihak), dilakukan uji normalitas dan homogenitas pada data pretes. Berdasarkan hasil uji normalitas dengan uji Kolmogorov Smirnov dan uji homogenitas dengan Levene Static menunjukkan bahwa data berdistribusi normal dan homogen.Berdasarkan hasil analisis uji kesamaan dua rerata dengan ujitmelalui program SPSS 20.0 for windows menggunakan Independent Sample T-Test dapat dilihat pada Tabel 2 berikut: 
Tabel 2. Hasil Uji Kesamaan Dua

\begin{tabular}{|c|c|c|}
\hline \multicolumn{3}{|c|}{ Rerata } \\
\hline & & Sig. (2-tailed) \\
\hline Pretes & $\begin{array}{c}\text { Equal } \\
\text { variances } \\
\text { assumed }\end{array}$ & 0,113 \\
\hline
\end{tabular}

Tabel diatas menunjukkan Sig. (2tailed) atau nilai signifikan untuk kemampuan awal (pretes) antara kelompok model pembelajaran inquiry training dan pembelajaran konvensional sebesar 0,113 ( $p>0,005)$. Hal ini berarti bahwa kemampuan awal (pretes) antara kelompok siswa yang diberi perlakuan model pembelajaran inquiry training dan pembelajaran konvensional menunjukkan tidak ada perbedaan yang signifikan $(\mathrm{p}>0,005)$. Maka dapat dimaknai bahwa kemampuan awal kedua kelompok adalah setara.

Hasil uji persyaratan hipotesis menunjukkan bahwa semua data postes berasal dari populasi yang berdistribusi normal dan mempunyai varians populasi yang homogen, sehingga pengujian hipotesis dengan teknik ANAVA dapat dilakukan. Hasil analisis data dengan ANOVA Univariate dari hasil belajar fisika melalui model pembelajaran inquiry training dan pembelajaran konvensional dengan motivasi tinggi dan rendah, dapat dilihat pada Tabel 3 berikut:

Tabel 3. Hasil Uji ANAVA Dua Jalur

Tests of Between-Subjects Effects

Dependent Variable: Postes

\begin{tabular}{|l|l|r|l|l|l|}
\hline Source & $\begin{array}{l}\text { Type III } \\
\text { Sum of } \\
\text { Squares }\end{array}$ & df & $\begin{array}{l}\text { Mean } \\
\text { Square }\end{array}$ & F & Sig \\
\hline Correc & 5490.275 & 3 & 1830.09 & 28.852 & .00 \\
ted & a & 2 & 0 \\
Model & 25 & 1 & 225 & 66 & 0 \\
Interc & 199233.2 & 199233. & 3140.9 & .00 \\
ept & 4100.625 & 1 & 4100.62 & 64.647 & .00 \\
Motiva & 5 & & 0
\end{tabular}

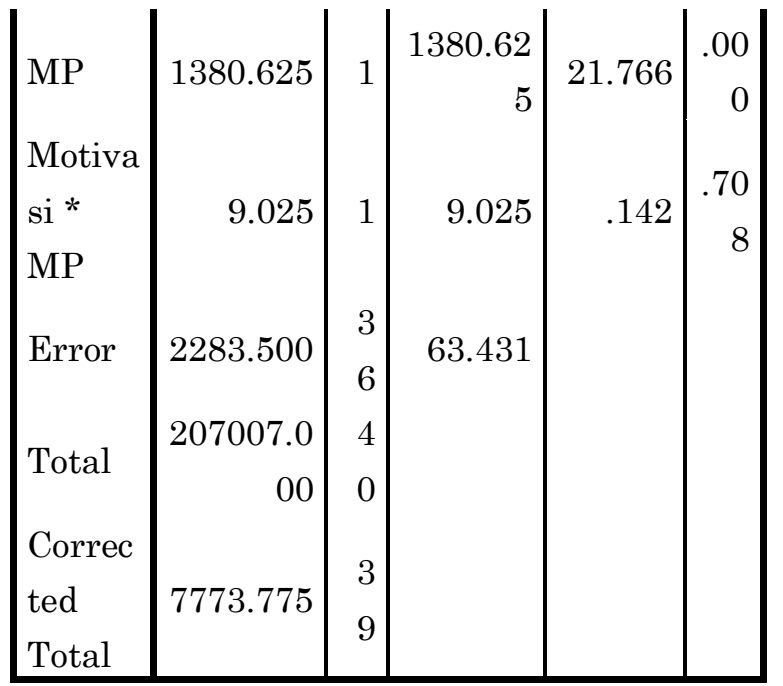

a. $\mathrm{R}$ Squared $=.706$ (Adjusted $\mathrm{R}$ Squared $=$ $.682)$

Berdasarkan tabel hasil uji ANAVA diatas, diperoleh informasi sebagai berikut:

1. Perbedaan Hasil Belajar Fisika Antara Model Pembelajaran Inquiry Training Dan Pembelajaran

Konvensional

Hasil perhitungan ANOVA Univariate menunjukkan $F_{\text {hitung }}=$ $21,766>\mathrm{F}_{\text {tabel }}=2,86$, dilihat dari signifikan $0,000<0,05$, artinya $\mathrm{H}_{0}$ ditolak dan $\mathrm{H}_{\mathrm{a}}$ diterima. Jadi ada perbedaan hasil belajar fisika dengan model pembelajaran inquiry training danpembelajaran konvensional.

2. Perbedaan Hasil Belajar Fisika Siswa yang Memiliki Motivasi Tinggi dan Siswa Yang Memiliki Motivasi Rendah

Tabel. 3 menjabarkan tentang hasil perhitungan analisis varians dua jalur menunjukkan bahwa $\mathrm{F}_{\text {hitung }}=$ 64,647 yang ternyata lebih besar dari $\mathrm{F}_{\text {tabel }}=2,86$. Dilihat dari signifikan $0,000<0,05, \mathrm{H}_{0}$ ditolak dan $\mathrm{H}_{\mathrm{a}}$ diterima Artinya ada perbedaan hasil belajar fisika siswa yang memiliki motivasi tinggi dan siswa yang memiliki motivasi rendah.

3. Interaksi Antara Model Pembelajaran Dengan Motivasi Terhadap Hasil Belajar 
Berdasarkan penjabarkan pada Tabel 3., hasil uji hipotesis ketiga, menggunakan ANAVA diperoleh nilai $\mathrm{F}_{\text {hitung }}=0,142$ lebih kecil dari $\mathrm{F}_{\text {tabel }}=$ 2,86 untuk taraf signifikan 0,05, sehingga $\mathrm{H}_{0}$ diterima, sedangkan $\mathrm{H}_{\mathrm{a}}$ ditolak. Jadi, tidak ada interaksi antara model pembelajaran dengan motivasi terhadap hasil belajar, seperti terlihat pada grafik dibawah ini:

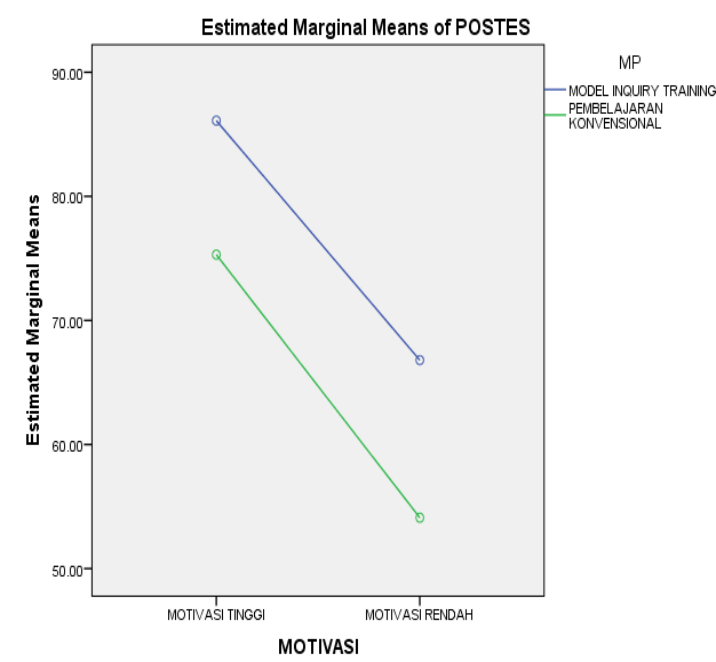

Gambar. Diagram interaksi antara model pembelajaran dengan motivasi terhadap hasil belajar

\section{Pembahasan Penelitian}

Model pembelajaran inquiry training dan pembelajaran konvensional pada dasarnya memberikan kesempatan bagi siswa sesuai dengan kemampuan yang dimilikinya untuk memperdalam pemahaman tentang konsep-konsep dasar yang dimilikinya, khususnya yang berkaitan dengan materi pokok yang dipelajari siswa, baik melalui guru maupun melalui belajar mandiri. Pembelajaran inquiry training adalah salah satu bentuk pembelajaran dan pengajaran yang terprogram dan merupakan salah satu pengajaran individu yang merujuk pada satu siasat untuk mengatur proses pengajaran sedemikian rupa sehingga setiap siswa memperoleh hasil belajar yang optimal.

Penelitian yang terkait dengan model pembelajaran inquiry trainingtelah diteliti oleh Njoroge, dkk., (2014) yang menyatakan bahwa terdapat perbedaan hasil belajar siswa yang signifikan dengan menerapkan pembelajaran berbasis inkuiri dibandingkan dengan penerapan pembelajaran konvensional.

Hasil temuan membuktikan bahwa hasil belajar fisika siswa yang menggunakan model pembelajaran inquiry training memiliki nilai ratarata yang lebih tinggi dibanding pembelajaran konvensional, dapat dilihat pada Tabel 4 dibawah ini.

Tabel 4. Nilai Rerata Dari Data Postes

\begin{tabular}{|c|c|c|c|}
\hline \multirow[b]{2}{*}{$\begin{array}{l}\text { Motiva } \\
\text { si }\end{array}$} & \multicolumn{2}{|c|}{ Model Pembelajaran } & \multirow[b]{2}{*}{$\begin{array}{l}\text { Rerat } \\
\text { a }\end{array}$} \\
\hline & $\begin{array}{l}\text { Inquiry } \\
\text { Training }\end{array}$ & $\begin{array}{l}\text { Pembelajar } \\
\text { an } \\
\text { Konvension } \\
\text { al }\end{array}$ & \\
\hline Tinggi & 86,10 & 75,30 & 80,70 \\
\hline $\begin{array}{l}\text { Renda } \\
\mathrm{h}\end{array}$ & 66,80 & 54,10 & 60,45 \\
\hline Rerata & 76,45 & 64,70 & \\
\hline
\end{tabular}

Rerata nilai siswa yang menggunakan model pembelajaran inquiry training adalah 76,45 serta rerata siswa yang menggunakan pembelajaran konvensional adalah 64,70. Hal ini dapat dipahami bahwa hasil belajar fisika di kelas eksperimen lebih tinggi dari pada kelas kontrol. Hal ini juga sejalan dengan penelitian Sirait (2012) yang menyatakan bahwa hasil belajar siswa dengan menggunakan model pembelajaran inquiry training meningkat.

Model pembelajaran inquiry training, membuat siswa yang diajar akan lebih bebas mengkomunikasikan temuan yang diperolehnya dengan kelompoknya pada saat melalukan kegiatan belajar. Komunikasi antar teman memberikan solusi yang cepat 
bagi siswa untuk melengkapi ketidaktahuannya tentang materi pokok yang dipelajari. Demikian, terdapat perbedaan hasil belajar fisika siswa dengan model pembelajaran inquiry training dan pembelajaran konvensional

Motivasi belajar sangat berpengaruh terhadap hasil belajar siswa. Siswa yang memiliki motivasi belajar rendah cenderung memperoleh nilai yang kurang memuaskan, sedangkan siswa yang memiliki motivasi tinggi akan selalu berusaha untuk mencapai prestasi sesuai dengan standar yang telah ditetapkan. Hal ini diperkuat oleh pendapat Hasan, dkk (2011) bahwa siswa yang memiliki motivasi belajar tinggi akan tekun dalam belajar dan terus belajar secara kontinyu tanpa mengenal putus asa serta dapat mengesampingkan hal-hal yang dapat mengganggu kegiatan belajar yang dilakukannya.

Penelitian yang terkait dengan perbedaan hasil belajar siswa yang memiliki motivasi tinggi dengan siswa yang memiliki motivasi rendah yaitu Hayati dan Suyanti (2013) yang menyatakan bahwa terdapat perbedaan hasil belajar fisika siswa pada kelompok siswa motivasi tinggi dan kelompok siswa motivasi rendah.

Hasil temuan dalam penelitian ini dapat dilihat pada Tabel 4, ditemukan bahwa kelompok siswa yang memiliki motivasi tinggi memiliki nilai hasil belajar fisika rata-rata sebesar 80,70. Sedangkan kelompok siswa yang memiliki motivasi rendah memiliki nilai hasil belajar fisika rata-rata sebesar 60,45. Hal ini dipahami bahwa hasil belajar fisika kelompok motivasi tinggi lebih tinggi dari kelompok motivasi rendah. Demikian, terdapat perbedaan hasil belajar fisika siswa yang memiliki motivasi tinggi dengan siswa yang memiliki motivasi rendah.

Analisis varians dua jalur juga menguji hipotesis ketiga yang menunjukkan hasil yang non signifikan. Kesimpulannya adalah tidak terdapat interaksi antara model pembelajaran dengan motivasi terhadap hasil belajar. Ketiadaan interaksi menunjukkan jika variabel bebas (model pembelajaran) dan variabel moderator (motivasi) lebih membawa pengaruh-pengaruh terpisah yang signifikan terhadap variabel terikat (hasil belajar). Hal ini sejalan dengan apa yang dikemukakan oleh Hair, dkk (1995) dan Kerlinger (2000), yang menyebutkan tidak terjadinya interaksi disebabkan jika dua variabel bebas atau lebih membawa pengaruhpengaruh secara terpisah yang sangat kuat (signifikan) terhadap variabel terikat. Pengaruh-pengaruh terpisah dari variabel bebas ini disebut pengaruh utama (main effect).

Temuan dalam penelitian ini juga sejalan dengan beberapa penelitian lainnya dari Tan (2011) yang menyimpulkan adanya pengaruh utama yang kuat dari variabel bebas dan variabel moderator terhadap variabel terikat, sehingga melemahkan interaksi yang ada, artinya model pembelajaran tidak memiliki interaksi yang kuat (signifikan) dengan motivasi terhadap perolehan hasil belajar siswa, dengan kata lain, tidak adanya interaksi tersebut karena tidak dominannya pengaruh model pembelajaran dari motivasi terhadap hasil belajar, atau sebaliknya pengaruh motivasi tidak lebih dominan dari model pembelajaran terhadap hasil belajar.

Ketiadaan interaksi antara model pembelajaran dan motivasi belajar terhadap hasil belajar juga dapat dilihat berdasarkan Gambar. 1 karena garis tidak saling berpotong maka tidak ada interaksi antara model pembelajaran dan motivasi belajar terhadap hasil belajar. Hal ini sejalan dengan yang dikemukakan oleh Sridewita dan Amar (2013) yang menyatakan bahwa ada tidaknya interaksi antara kedua variabel dapat ditunjukkan secara grafis, yaitu dengan grafik diperoleh kedua garis berpotongan maka dia saling 
berinteraksi namun jika tidak berpotongan maka dia tidak saling berinteraksi.

Sebaiknya untuk penelitian selanjutnya yang sejenis pada motivasi. Siswa tidak perlu dibagi berdasarkan tingkatan motivasinya, sebab pada penelitian ini tingkat motivasi siswa dan model pembelajaran secara bersama-sama tidak memberikan perbedaan hasil yang signifikan terhadap hasil belajar siswa. Siswa yang memiliki motivasi tinggi dan siswa yang memiliki motivasi rendah secara bersama-sama dapat mengikuti proses pembelajaran dengan diberi perlakuan atau tidak tanpa harus di bagi atau di pisah, hal ini dikarenakan model pembelajaran dan motivasi membawa pengaruh masing-masing yang sama kuat. Demikian, tidak terdapat interaksi antara model pembelajaran dengan motivasi belajar siswa untuk meningkatkan hasil belajar siswa

\section{SIMPULAN}

Berdasarkan hasil analisa data dan pembahasan dapat disimpulkan sebagai berikut:

1. Terdapat perbedaan hasil belajar fisika antara siswa yang menggunakan model Inquiry Training dibanding dengan siswa yang menggunakan model pembelajaran kooperatif.

2. Terdapat perbedaan hasil belajar fisika siswa yang memiliki motivasi belajar tinggi lebih baik dari pada siswa yang memiliki motivasi belajar rendah.

3. Tidak terdapat interaksi antara model pembelajaran dengan motivasi terhadap hasil belajar siswa.

\section{DAFTAR PUSTAKA}

Aunnurrahman, (2009), Belajar dan Pembelajaran, Alfabeta, Bandung.

Djamarah, S., B., (2011), Psikologi Belajar, Rineka Cipta, Jakarta.

Febrianto, B dan Rani, I.G., (2013), Hubungan Motivasi Belajar Dengan
Hasil Belajar Bahan Bangunan Siswa Kelas X Bangunan Di SMKN 1 Tanjung Raya, CIVED 1(2): 133-141

Hair, J.F., Anderson, R.E., Tatham, R,L，\& Black, W, C, (1995), Multivariate Data Analysis With Reading, Fourth Edition, PrenticeHall, Inc, New Jersey

Harahap, A., R dan Sinuraya, J., B., (2014), Pengaruh Model Pembelajaran Inkuiri Terhadap Hasil Belajar Siswa Pada Materi Pokok Listrik Dinamis Di Kelas X SMA Swasta Al Ulum Medan T.P. 2013/2014, Jurnal INPAFI, 2(3): 1-9

Hayati dan Suyanti, R., D., (2013), Efek Model Pembelajaran Inquiry Training Berbasis Multimedia Dan Motivasi Terhadap Hasil Belajar Fisika Siswa, Jurnal Online Pendidikan Fisika2(1): 24-31

Hasan, P., Pariabti dan Ali, M., S., (2011), Hubungan Antara Pengetahuan Dasar Matematika Dan Motivasi Belajar Dengan Hasil Belajar Fisika Siswa Kelas XI IPA SMA NEGEI 1 Makassar Tahun Ajaran 2010/2011, JSPF17: 93-107

Joyce, B., Wheil, M., dan Calhoun, E. (2011), Models of Teaching (ModelModel Pengajaran) Edisi Kedelapan, Pustaka Pelajar, Yogyakarta.

Kerlinger, F, N., (2000), Foundations Of Behavioral Research, Fourth Edition, Wadsworth Publishing Company, California

Nasution, N., A., (2015), Studi Pendahuluan, Tidak Dipublikasikan.

Njoroge, G, N., Changeiywo, J, M., dan Ndirangu, M., (2014), Effects of Inquiry-based teaching approach on Secondary School Students' Achievement and Motivation in Physics in Nyeri County, Kenya, International Journal of Academic Research in Education and Review, 2(1): 1-16

Pandey, A., Nanda, G.K, and Ranjan, V (2011). Effectiveness of Inquiry Training Model Over Conventional Teaching Method on Academic Achievement of Science Students in 
India, Journal of Innovative Research in Education 1(1): 7-20

Prayitno, E, (1989), Motivasi Dalam Belajar, PPLPTK Depdikbud, Jakarta.

Sardiman, A., M., (2011), Interaksi \& Motivasi Belajar Mengajar, Rajawali Pers, Jakarta.

Sirait, R., (2012), Pengaruh Model Pembelajaran Inquiry Training Terhadap Hasil Belajar Terhadap Hasil Belajar Siswa Pada Materi Pokok Usaha dan Energi Kelas VIII MTs N-3 Medan, Jurnal Pendidikan Fisika 1(1): 21-26

Sridewita, H dan Amar S., (2013), Pengaruh Model Pembelajaran Mind Mapping dan Motivasi Terhadap
Hasil Belajar Siswa Mata Pelajaran Ekonomi di SMA N 1 Tanjung Raya, (online) 4239-8754-1-SM.pdf diakses 31 Mei 2015

Sumiati dan Asra, (2013), Metode Pembelajaran, Wacana Prima, Bandung.

Tan, I.G.C., (2011), Effect Of Group Investigation In Academic Achievement and Motivation of High And Low Ability Student in Singapore Secondary School, (online), http:///www.iasce.net/publications.ht

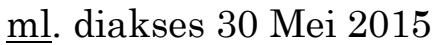

Trianto, (2011), Mendesain Model Pembelajaran Inovatif - $^{-}$ Progresif, Kencana, Jakarta. 